\title{
Contribution and Training Effect for Social Worker
}

\author{
Nani Sintiawati \\ Non Formal Education Department, \\ Post Graduate School Universitas Pendidikan Indonesia \\ Bandung, Indonesia \\ Nanisintiawati09@Student.upi.edu
}

\begin{abstract}
Human resource development is a series of planned activities designed by the organization to give opportunity for members to learn the skills needed to meet the requirements of the current work and their future job. The training is informal education that became one of the efforts in the development of human resources. Social workers are required to have a special ability both in planning services development models, evaluate social policy. Therefore BBPPKS Bandung, as training institutions have the responsibility of strengthening the competence of social workers through the training event. This article will describe how the contribution and the effects of a training in improving the performance of human resources. The success of the development and the ministry of social welfare is influenced by the performance of the professional social worker. This research focuses on the management of the training that shows an impact on the performance of human resources in Bandung BBPPKS, in this case social worker. The discussion is done with how to compare the results of the empirical research with the theory. The research is implicated to the social workers welfare relates to social service. Professional social service is the social worker users' demand on these days. The accuracy and pace in using the social service approachment becomes one of indicators that the given service is professional. According to those things, the social worker has improved their knowledge and ability by doing the training in order to build a better social service.
\end{abstract}

Keywords - Training, Development, Performance, Social service, Human Resources, Social Worker

\section{INTRODUCTION}

Social worker is a human resources assigned to serve the community. In order to realize the welfare of the community social workers should have a good performance. It can be felt by the institution also society.

Education and training Institutions are able to create the quality and quantity of human resources to meet the needs of the wider community, so they can actualize the servants that provide services and the quality of work for the interests of the community.

Regarding quality and quantity, performance is the work of both the quality and quantity of that achieved by a person in carrying out the tasks according to the given responsibility. Based on the problem above, this article will describe how the contribution and the effects of a training held by an institution of social worker performance measured by the attitude that is produced from the social observation.
There are some study results that relevant to the observation in contributing the training for improving the performance of human resources. Felicia and Lavinia reveals the human resources development strategy should be integrated in the national and regional program as an effort to increase the economic growth through several stages : identification, partnership, analyzes the theory and practice that is at the global level and national [1]. In view of the fact that human resource training projects are primarily focused on improvement of organizational performance, the congruence of training participants' and their managers' expectations about such projects is significant [2]. Training is the most important and frequently used human resource development activity and organizations devote a substantial percentage of their budgets to it [3].

Other research is talking about the training and capacity building evaluation: maximize resources and result with Success Case Method [3]. Success Case Method has been used in health care settings to measure the value of training and report that value back out to the organization of training evaluation [3]. A social worker is a person who carries out social investigations and ensures social agendas. This includes addressing social-legal issues in facilities that provide social services, social-legal counselling, analytical, methodological and conceptual activities in the social sector, professional activities in facilities that provide social prevention services, screening activities, the provision of emergency assistance, social counselling, social rehabilitation, ascertaining the needs of people in the local community and the region, and coordinating the provision of social services [4]. In order for an individual to carry out the work of a social worker, the individual must be fully legally competent, irreproachable and physically and professionally qualified. The process of qualifying to be a social worker is a rather lengthy one; from a novice to an educated, experienced, senior and advanced practitioner [4].

Research about training in Bangkok, Competency-based training to develop basic computer skills for the elder in Dusit community, Bangkok, Thailand was to find learning achievement of basic computer knowledge and skill training of people in the mentioned area. After the training, the people should be able to access information technology system efficiently. The results showed that after the training, the trainees reported learning achievement at a statistically significant level of 0.05 and an increasing of learning achieved at an average of 6.82 [5]. According to human capital theories, 
training is an investment in human capital and should enhance the individual's work skills and productivity, enabling the worker to receive a wage in keeping with this enhanced productivity. Most of these studies show the positive effects of training [6]. Conclusion order to improve employee training and development in the municipality, and improved performance and service delivery, management should increase the number of employees taking part in training and development [7]. In other research, training leaders using a functional leadership program would improve the effectiveness of their teams and that their teams' performance would be better than that of teams led by untrained leaders [8].

\section{METHODS}

This research done in BPPKS Bandung. This research aims to investigate the contribution of securities and training of social workers in BBPPKS Bandung. The methods used in the collection of research data is a quantitative method. This Research focuses on the management of the training that shows an impact on the performance of human resources in Bandung BBPPKS, in this case social worker.

The discussion is done with how to compare the results of the empirical research with the theory. The process of this research refers to the data in order to reveal the data on the performance of the employees, whether there is a significant impact between the management of the training to the performance of civil servants or not will be proven by the results from the analysis of the data. Data collection is done by spreading the questioner to alumni of the participants in the training (Social Worker), then processed into the data statistic that later will be elaborated through the form data and narration.

\section{A. To improvement managerial Training}

In the context of training, management is used to that implement learning effectively and efficiently. Thus, the steps of management conducted are planning, organizing and implementation and evaluation or follow up. Moreover, Sudjana (2000) reveals that training management activities "consist of planning, organizing, implementation and evaluation "[9].

\section{B. Performance}

The performance is the level of success of a person comprehensively for a certain period in carrying out the tasks compared with various possible, as the work standard of the targets or objectives or criteria that has been determined before [10].

\section{RESULTS AND DISCUSSIONS}

Investigations regarding the effect of the training on the performance of the social worker has been proven by the data presented quantitatively by the author and a model of the management of the training become the most important part from a training.

Based on the testing of the hypothesis that has been done previously by SPSS statistics 20.0 for windows. The results of multiple regression analysis, obtained the conclusion that the training of social workers between training management variable as part of the effort to improve the performance of the social worker in Bandung BBPPKS has significant relationships.

TABLE I. CORRELATION COEFFICIENT INTREPRETASI GUIDELINES

\begin{tabular}{|c|c|}
\hline $\begin{array}{c}\text { The value of the lowest } \\
\text { infection rate }\end{array}$ & $\begin{array}{c}\text { Relationship Level } \\
\text { Coefficient }\end{array}$ \\
\hline $0.00-0,199$ & Very Low \\
\hline $0.20-0,399$ & Low \\
\hline $0.40-0,599$ & is \\
\hline $0.60-0,799$ & strong \\
\hline $0.80 \mathrm{hld}-1,000$ & very strong \\
\hline
\end{tabular}

The result obtained from the statistical data analysis showed that the $Y=13,260+\mathbf{0 , 9 2 8} X$. The description of this equation gives the meaning that better training management process the higher employees performance.

Then the correlation coefficient obtained from both variables is as much as $92.4 \%$. This means that the results of the training variable gave contribution of 92.4 percent against the performance of employees and the rest 7.6 percent influenced by other variables.

The research shows the level of the drag coefficient statistically and the details descriptively. The writer is trying to observe and analyze how the level of the drag coefficient between research variables very correlates highly. There are several factors that were supposed to be supporting factor that make training contribute to the performance of human resources. A series of research results and discussion of the research in this chapter is outlined by the authors that the training event in Bandung BBPPKS is good. Because on its implementation, the organizer of the training has been systematically draw up and implement the aspects of the training management. Those aspects are preparation stage, organizing stage, the implementation stages and the final evaluation stage. The management activities have contribution and effect for the improvement of the performance of the human resource in BBPPKS Bandung. All of the steps provide benefits indirectly towards the implementation of the training from the beginning to the end. So the author is trying to expose the form Model flow management of the training in fig. 1 that was held in Bandung BBPPKS. 


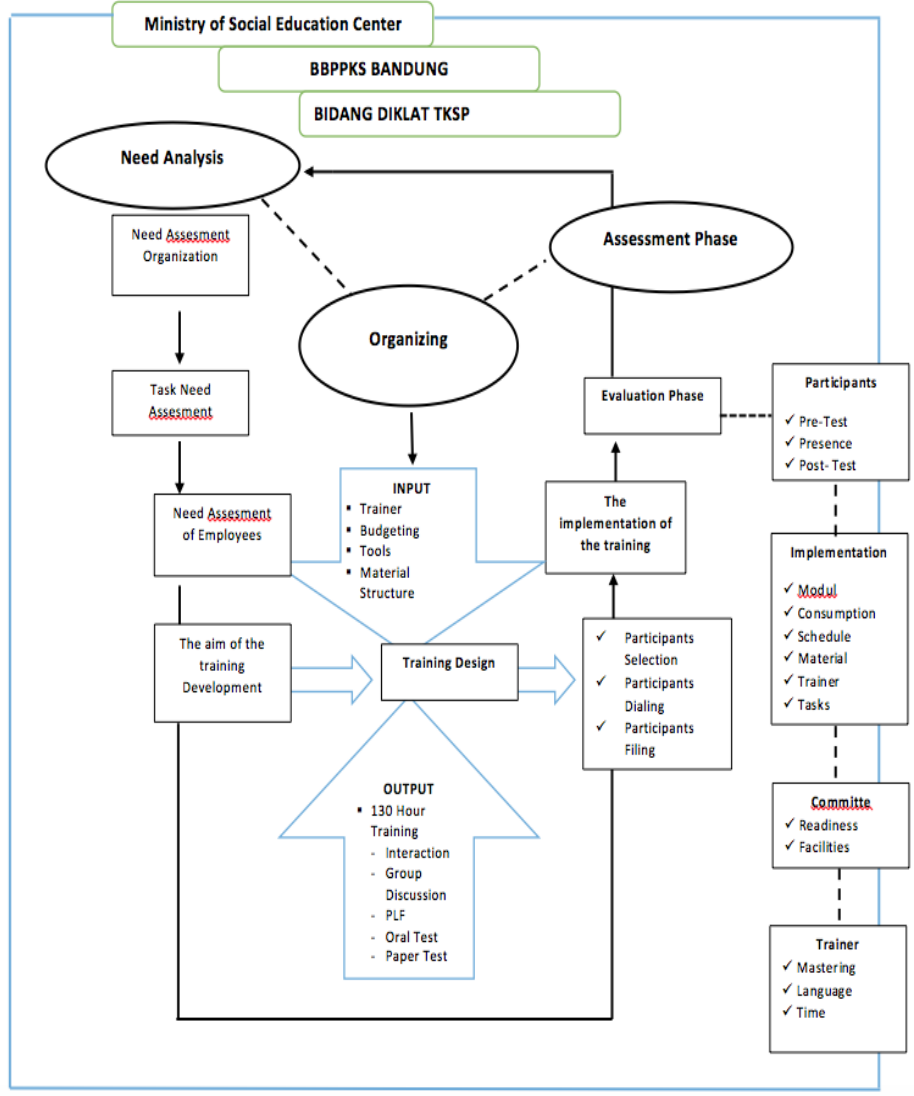

Fig. 1. The Training Management Model Social Worker BBPPKS Bandung

The model of the training management is being the reason behind the creation of the relationship between the training process and the performance of human resources. Why? This is because training cannot be established effectively without any organizing, implementation and evaluation of the targeted by the organizer of the training. In the analysis that the model used by BBPPKS Bandung is to manage training with through three stages: needs analysis, organizing and training assessment stage. Based on an evaluation of the training on the final stage, found that the results of the questionnaire from stakeholders, there is a change in attitude that felt by the stakeholders before and after attending the training.

The changes can be seen from the changes in the motivation to work, the emergence of independence, activity involving, and cooperation in groups. The changing expertise/skills and responsibility felt by the respondents were influenced by the knowledge and skills that lead to changes in attitudes and behaviors to receive and do the benefits of the training which has been following.

In line with the expressed by the Kreck (T.Fandy, 2001, p.30.43) which revealed that "the attitude of the individual is formed by the received information, changes the attitude of the individual in the relationship with various objects can cause this attitude stronger or vice versa. This depends on the experience of the individual in their attitude."

\section{CONCLUSION}

The training event is intended to develop the human resources in the national development efforts. A government institutions as well as private institutions basically must hold training in order to improve the quality and quantity of the performance of workers. The training event with a systematic management model can contribute to the participants to improve the performance of civil servants. After the research is complete, the result can be used to be one of the training management models in government institutions or in private institutions. And the most of these studies show the positive effects of training.

\section{ACKNOWLEDGMENT}

The author would like to say thank you to majoring in the Department of Non Formal Education, Post Graduate School Universitas Pendidikan Indonesia, which has provided an opportunity for writers to contribute in this research.

\section{REFERENCES}

[1] Andrioni, F., \& Popp, L. E. (2012). "Plea for the development of human resources through professional training in Romania." Procedia -Social and Behavioral Sciences, 62, 413-417. http://doi.org/10.1016/j.sbspro.2012.09.067

[2] Erina, I., Ozolina-Ozola, I., \& Gaile-Sarkane, E. (2015). "The Importance of Stakeholders in Human Resource Training Projects." Procedia - Social and Behavioral Sciences, 213, 794-800. http://doi.org/10.1016/j.sbspro.2015.11.477

[3] Medina, L., Acosta-Pérez, E., Velez, C., Martínez, G., Rivera, M., Sardiñas, L., \& Pattatucci, a. (2015). "Training and capacity building evaluation: Maximizing resources and results with Success Case Method. Evaluation and Program Planning," 52, 126-32. http://doi.org/10.1016/j.evalprogplan.2015.03.008

[4] Borsk, J, \& Vejdarov, S. (2016). "Legal regulation of training of social workers in the Czech Republic." Kontakt, 18(1), e42-e48. http://doi.org/10.1016/j.kontakt.2016.01.004

[5] Meethongjan, K. \& Tachpetpaiboon, N. (2015). "Competency-based Training to Develop Basic Computer Skills for the Elderly: A Case Study of the Dusit Community, Bangkok, Thailand." Procedia - Social and Behavioral Sciences, 197(February), 2520-2525. http://doi.org/10.1016/j.sbspro.2015.07.327

[6] Hara, H. (2014). "The impact of firm-provided training on productivity, wages, and transition to regular employment for workers in flexible arrangements." Journal of the Japanese and International Economies, 34(October 2012), 336-359. http://doi.org/10.1016/j.jjie.2014.10.002

[7] Mpofu, M., \& Hlatywayo, C. K. (2015). "Training and development as a tool for improving basic service delivery; the case of a selected municipality." Journal of Economics, Finance and Administrative Science, 20(39), 133-136. http://doi.org/10.1016/j.jefas.2015.10.004

[8] Santos, J. P., Caetano, A., \& Tavares, S. M. (2015). "Is training leaders in functional leadership a useful tool for improving the performance of leadership functions and team effectiveness? Leadership Quarterly," 26(3), 470-484. http://doi.org/10.1016/j.leaqua.2015.02.010

[9] Sudjana, D. (2000). Manajemen Program Pendidikan untuk Pendidikan Nonformal dan pengembangan sumber daya manusia. Bandung: fallah production

[10] Rivai, \& Basri. (2005). Peformance Appraisal: Sistem yang tepat untuk Menilai Kinerja Karyawan dan Meningkatkan Daya Saing Perusahan. Jakarta: PT. Raja Grafindo Persada. 